\title{
Biodegradable Materials with Disulfide-Bridged-Framework Confine Photosensitizers for Enhanced Photo-Immunotherapy [Corrigendum]
}

\author{
Li D, Chen F, Cheng C, Li H, Wei X. Int J Nanomedicine. \\ 2022;16:8323-8334.
}

On page 8323, the Methods and Results sections have been updated. The revised abstract section should read as follows:

Purpose: Photodynamic therapy (PDT) with spatiotemporal controlled and noninvasive advantages has obtained growing attention in cancer treatment. Nevertheless, PDT still suffers from self-aggregation-induced photosensitizer quenching and reactive oxygen species (ROS) scavenging in cancer cells with abundant glutathione (GSH) pools, leading to insufficient performance.

Methods: Photosensitizer Ce6-loaded nanocarrier (SSNs) with a disulfide-bond-bridged silica framework were developed for enhanced photo-immunotherapy. After studying the GSH-responsive matrix degradation and controlled release of $\mathrm{Ce} 6$, the GSH depletion and ROS generation were determined. The tumor killing and immunogenic cell death effects of SSNs@Ce6-mediated phototherapy were investigated in vitro. The tumor accumulation, therapeutic efficacy and safety profile of photoimmunotherapy were also evaluated in vivo.
Results: Such SSNs spatially confine photosensitizer Ce6 in the matrix to prevent self-aggregation. Under the high GSH level of cancer cells, the disulfide-bond-bridged framework was degradable and triggered the exposure of photosensitizers to oxygen, accelerating the ROS generation during PDT. In addition, GSH depletion via the break of the disulfide-bond increased the ROS level, together resulting in efficient tumor killing outcomes with a considerable immunogenic cell death effect in vitro. Importantly, the SSNs@Ce6 accumulated in the tumor site and exhibited enhanced PDT efficacy with low systemic toxicity in vivo. Notably, SSNs@Ce6-miediated PDT completely eradicated 4T1 tumors when combined with the PD-1 checkpoint blockade.

Conclusion: The confinement of photosensitizers in a biodegradable disulfide-bridged-framework provides a promising strategy to unleash the potential of photosensitizers in PDT, especially in combined cancer photoimmunotherapy.

The authors apologize for this error and advise it does not affect the results of the paper.
International Journal of Nanomedicine

\section{Publish your work in this journal}

The International Journal of Nanomedicine is an international, peerreviewed journal focusing on the application of nanotechnology in diagnostics, therapeutics, and drug delivery systems throughout the biomedical field. This journal is indexed on PubMed Central, MedLine, CAS, SciSearch ${ }^{\mathbb{B}}$, Current Contents ${ }^{\mathbb{B}} /$ Clinical Medicine,

\section{Dovepress}

Journal Citation Reports/Science Edition, EMBase, Scopus and the Elsevier Bibliographic databases. The manuscript management system is completely online and includes a very quick and fair peer-review system, which is all easy to use. Visit http://www.dovepress.com/ testimonials.php to read real quotes from published authors. 